\title{
MODEL-MODEL INTEGRASI KEILMUAN PERGURUAN TINGGI KEAGAMAAN ISLAM
}

\author{
Nur Jamal \\ STAI Nazhatut Thullab Sampang \\ E-mail: jamalnr73@yahoo.com
}

\begin{abstract}
Abstrak:
Tulisan ini membahas tentang integrasi keilmuan Islam, hal ini dilatarbelakangi oleh adanya dualisme atau dikotomi keilmuan antara ilmu-ilmu umum di satu sisi dengan ilmu-ilmu agama di sisi lain. Yang kemudian berimplikasi luas terhadap aspek-aspek kependidikan di lingkungan umat Islam, baik yang menyangkut cara pandang umat terhadap ilmu dan pendidikan, kelembagaan pendidikan, kurikulum pendidikan, maupun psikologi umat pada umumnya. Mode-model integrasi keilmuan dapat berupa model IFIAS, ASASI, Islamic Worldview, Struktur Pengetahuan Islam, Model Bucaillisme, Integrasi Keilmuan Berbasis Filsafat Klasik, Integrasi Keilmuwan Berbasis Tasawuf, Integrasi Keilmuwan Berbasis Fiqh, Model Kelompok Ijmali, Model Kelompok Aligarh.
\end{abstract}

Kata Kunci : Model, integrasi, ilmu

\section{Abstract:}

This paper discusses the integration of Islamic scholarship, it is motivated by scientific dualism or dichotomy between general sciences on the one hand with the religious sciences on the other. Which then broad implications for aspects of education in the Muslim community, both involving the community perspective on science and education, educational institutions, educational curricula, as well as people in general psychology. Fashion-model of integration of science can be IFIAS models, RIGHTS, Islamic Worldview, Islamic Knowledge Structure, Model Bucaillisme, Scientific-Based Integration Classical Philosophy, IntegrationBased Science of Sufism, Integration-Based Science of Fiqh, Ijmali Group Model, Model Group Aligarh.

Keywords: Model, integration, science 


\section{Pendahuluan}

Ide tentang integrasi keilmuan Islam di kalangan para pemikir pendidikan Islam di Indonesia selama ini dipandang masih berserakan dan belum dirumuskan dalam suatu tipologi pemikiran yang khas, terstruktur, dan sistematis. Bahkan transformasi beberapa IAIN/STAIN menjadi UIN pun dipandang belum menggambarkan peta pemikiran keilmuan Islam, baik di Indonesia maupun di dunia Islam pada umumnya baik masa klasik maupun kontemporer. Itulah sebabnya berbagai gagasan integrasi keilmuan, termasuk juga kristalisasinya dalam bentuk transformasi IAIN/STAIN menuju UIN menjadi penting untuk membangun suatu tipologi atau pemikiran tentang integrasi keilmuan Islam.

Awal munculnya ide tentang integrasi keilmuan dilatarbelakangi oleh adanya dualisme atau dikotomi keilmuan antara ilmu-ilmu umum di satu sisi dengan ilmui-lmu agama di sisi lain. Dikotomi ilmu yang salah satunya terlihat dalam dikotomi institusi pendidikan antara pendidikan umum dan pendidikan agama telah berlangsung semenjak bangsa ini mengenal sistem pendidikan modern. Dikotomi keilmuan Islam tersebut berimplikasi luas terhadap aspek-aspek kependidikan di lingkungan umat Islam, baik yang menyangkut cara pandang umat terhadap ilmu dan pendidikan, kelembagaan pendidikan, kurikulum pendidikan, maupun psikologi umat pada umumnya.

Berkenaan dengan cara pandang umat Islam terhadap ilmu dan pendidikan, di kalangan masyarakat Islam berkembang suatu kepercayaan bahwa hanya ilmu-ilmu agama Islamlah yang pantas dan layak dikaji atau dipelajari oleh umat Islam, terutama anakanak dan generasi mudanya. Sementara ilmu-ilmu sekuler dipandang sebagai sesuatu yang bukan bagian dari ilmu-ilmu yang layak dan patut dipelajari. Cara pandang dengan menggunakan perspektif oposisi biner terhadap ilmu secara ontologis ini, kemudian berimplikasi juga terhadap cara pandang sebagian umat Islam terhadap pendidikan.

Sebagian umat Islam hanya memandang lembaga-lembaga pendidikan yang berlabel Islam yang akan mampu mengantarkan anak-anak dan generasi mudanya mencapai cita menjadi muslim yang sejati demi mencapai kebahagiaan di dunia dan di akhirat. Sementara itu, lembaga-lembaga pendidikan "umum" dipandang sebagai lembaga pendidikan sekuler yang tidak kondusif mengantarkan anak-anak dan generasi muda Islam menjadi Muslim sejati yang diidolakan orang tua. Kontras dengan cara pandang di atas adalah pandangan yang juga dimiliki oleh sebagian 
umat Islam. Mereka lebih cenderung memilih lembaga-lembaga pendidikan umum dengan pertimbangan jaminan mutu serta jaminan pekerjaan yang bakal diperoleh setelah lulus. Bagi mereka ini, lembaga pendidikan yang berlabel Islam cenderung dipandang sebagai tradisional, ketinggalan zaman, dan oleh karena itu mutu dan kesempatan kerja setelah lulus tidak terjamin.

Selanjutnya dalam pandangan beberapa tokoh Islam yang memiliki sudut pandang inklusif, modernisasi pendidikan Islam menjadi suatu keharusan. Disamping tuntutan zaman dan perkembangan arus globalisasi, juga terdapat beberapa alasan antara lain: pertama, meningkatkan daya saing siswa dilembaga pendidikan Islam dengan siswa yang ada di pendidikan umum. Kedua, Dapat disadari bahwa, lembaga pendidikan Islam hanya dapat bertahan lama setelah memasukkan materi-materi umum ke lembaga pendidikan Islam. Ketiga, Masyarakat cenderung lebih berminat menyekolahkan anaknya ke lembaga pendidikan yang ada materi pelajaran umum. Dengan alasan terciptanya harmonisasi kebutuhan spiritual dan material (duniawi dan ukhrawi). Keempat, Kesadaran para pengelola lembaga pendidikan Islam bahwa tidak semua alumni pesantren ingin menjadi seorang ulama, ustadz maupun da'i. tetapi mereka tetap memposisikan dirinya sebagai rakyat biasa yang ingin mengasah diri, meningkatkan ilmu pengetahuan dan keterampilan lainnya dalam rangka menatap masa depan yang lebih cerah (persaingan dalam dunia kerja). ${ }^{1}$

Hal inilah yang menjadi latar belakang penulis menyusun makalah ini dengan judul "Integrasi antara Keilmuan Umum dan Agama".

\section{Dasar Integrasi Keilmuan Umum dan Agama}

Hingga kini, masih kuat anggapan dalam masyarakat luas yang mengatakan bahwa "agama" dan "ilmu", "madrasah" dan "sekolah" adalah dua entitas yang tidak bisa dipertemukan. Keduanya mempunyai wilayah sendiri-sendiri, terpisah antara satu dan lainnya, baik dari segi objek formal-material keilmuan, metode penelitian, kriteria kebenaran, peran yang dimainkan oleh ilmuwan maupun status teori masing-masing bahkan sampai ke institusi penyelenggaraannya. Dengan lain ungkapan, ilmu tidak mempedulikan agama dan agama tidak mempedulikan ilmu. Begitulah sebuah gambaran praktik kependidikan dan aktivitas

${ }^{1}$ Moh Wardi, “Modernisasi Muallimin”, Jurnal Ta'limuna al-Hikam Malang, Vol. 7 No. 1 Maret 2014, 90. 
keilmuan di tanah air sekarang ini dengan berbagai dampak negatif yang ditimbulkan dan dirasakan oleh masyarakat luas. ${ }^{2}$

Dalam sejarah hubungan ilmu dan agama di Barat, pemimpin gereja menolak teori heliosentris Galileo atau teori evolusi Darwin. Pemimpin gereja membuat pernyataan-pernyataan yang berada diluar bidang kompetensinya. Sebaliknya Isaac Newton dan tokoh ilmu-ilmu sekuler yang lain menempatkan Tuhan hanya sekedar sebagai penutup sementara lubang kesulitan (to fill gaps) yang tidak terpecahkan dan terjawab oleh teori keilmuan mereka, sampai tiba waktunya diperoleh data yang lebih lengkap atau teori baru yang dapat menjawab kesulitan tersebut. Begitu kesulitan itu terjawab, maka secara otomatis intervensi Tuhan tidak lagi diperlukan. Dengan begitu do'a yang menjadi inti beragama, tidak lagi diperlukan. Akhirnya Tuhan dalam benak para ilmuan hanya ibarat pembuat jam (clock maker). Begitu alam semesta ini selesai diciptakan, ia tidak peduli lagi dengan alam raya ciptaan-Nya dan alam semesta pun berjalan sendiri secara mekanis tanpa campur tangan tujuan agung ketuhanan. ${ }^{3}$

Sekarang ini pembaharuan-pembaharuan pendidikan di seluruh dunia Islam lebih dipacu untuk membangun tiruan-tiruan terhadap tonggak intelektual Barat daripada membentuk kembali sumber akalnya sendiri. Jika kita tidak mendefinisikan kembali tingkattingkat konseptual yang sesuai dengan warisan-warisan klasik kita, sebagaimana mendefinisikan kembali pandangan dunia Islam, maka kita hanya akan menoreh luka-luka intelektual kita sebelumnya. Ummat Islam dengan pandanan dunianya sendiri, memiliki dua tanggung jawab terhadap dirinya sendiri. Pertama, untuk membuat dan menghasilkan dasar ilmunya sendiri, yang merupakan sebuah sistem untuk menghasilkan pengetahuan pribumi yang organis. Kedua, tanggung jawab moral terhadap umat manusia dan alam untuk menjamin bahwa keduanya berada pada kondisi kesejahteraan material dan spiritual yang terbaik. ${ }^{4}$

Sementara itu, dalam dunia pendidikan Islam muncul dua fenomena: Pertama, yang umum terjadi adalah pengajaran ilmuilmu agama Islam yang normatif-tekstual terlepas dari perkembangan ilmu-ilmu sosial, ekonomi, hukum, humaniora dan ilmu-ilmu agama (religious studies) pada umumnya. Kedua,

\footnotetext{
${ }^{2}$ Amin Abdullah, Islamic Studies, (Bandung: Pustaka Pelajar, 2006), 93

3 Ibid

${ }^{4}$ Munawar Ahmad Anees, Menghidupkan Kembali Ilmu Dalam Jurnal-Jurnal Studi Islam, (Bandung: Yayasan Mutahhari, 1991), 83.
} 
pendidikan ilmu-ilmu kealaman (Iptek) "dipaksa" kawin dengan ilmu-ilmu keagamaan Islam yang normative tekstual dengan cara melekatkan dan menempelkan ayat-ayat pada temuan dan keberhasilan Iptek, namun terlepas begitu saja dari perkembangan ilmu-ilmu sosial dan humaniora. Perbedaan itu semakin hari semakin jauh ibarat deret ukur terbalik, dan membawa akibat yang tidak nyaman bagi kehidupan intern dan lebih-lebih ekstern umat beragama. Pola pikir yang serba dikotomis ini menjadikan manusia terasing dari nilai-nilai spiritualitas-moralitas, rendah pemahaman etika sosialnya, terasing dari dirinya sendiri, terasing dari keluarga dan masyarakat sekelilingnya, terasing dari lingkungan alam dan ragam hayati yang menopang kehidupannya serta terasing dari denyut nadi lingkungan sosial-budaya sekitarnya. Singkatnya, terjadi proses dehumanisiasi secara pasif baik pada tataran kehidupan keilmuan, keagamaan, sosial-politik dan sosial-ekonomi.

Merumuskan konsep pendidikan Islam memang bukanlah pekerjaan yang ringan sebab rumusan tersebut harus mengkaitkan Islam sebagai disiplin ilmu. Dalam upaya merekonstruksi pendidikan Islam, kita perlu memperhatikan prinsip-prinsip pendidikan Islam, yang meliputi: pertama, Pendidikan Islam merupakan bagian dari sistem kehidupan Islam, yaitu proses internalisasi dan sosialisasi nilai-nilai moral Islam melalui sejumlah informasi, pengetahuan, sikap, perilaku dan budaya. Kedua, Pendidikan Islam merupakan sesuatu yang integred artinya mempunyai kaitan yang membentuk suatu kesatuan yang integral dengan ilmu-ilmu yang lain. Ketiga, Pendidikan Islam merupakan life long process sejak dini kehidupan manusia. Keempat, Pendidikan Islam berlangsung melalui suatu proses yang dinamis, yakni harus mampu menciptakan iklim dialogis dan interaktif antara pendidik an peserta didik. Kelima, Pendidikan Islam dilakukan dengan memberi lebih banyak mengenai pesan-pesan moral pada peserta didik. ${ }^{5}$

Adanya keterpisahan secara diametrikal antara keduanya dan sebab-sebab lain yang bersifat politis-ekonomis, berakibat pada rendahnya kualitas pendidikan dan kemunduran dunia Islam pada umumnya. Dalam ketiga revolusi peradaban manusia, yaitu revolusi hijau, revolusi industri dan revolusi informasi, tak satupun ilmuan Muslim tercatat namanya dalam lembaran tinta emas pengembang ilmu pengetahuan. Perkembangan dan pertumbuhan ilmu-ilmu sekolahan-sekuler sebagai simbol keberhasilan sekolah

5 Zainuddin, Filsafat Ilmu Perspektif Pemikiran Islam, (Malang: Lintas Pustaka, 2006), 137. 
dan perguruan tinggi umum dengan berbagai implikasinya pada tataran moral dan etik kehidupan manusia di seluruh dunia di satu pihak, dan perkembangan dan pertumbuhan madrasah dan perguruan tinggi agama yang hanya menekankan ilmu-ilmu keagamaan dan teks-teks keislaman normatif-klasik dengan berbagai dampaknya pada penciptaan tenaga terampil dalam dunia ketenagakerjaan di lain pihak, menjadikan kedua-duanya mengalami proses pertumbuhan yang tidak sehat serta membawa dampak negatif bagi kehidupan sosial-budaya, sosial-ekonomi, sosial-politik dan sosial-keagamaan di tanah air.

Dari sini tergambar bahwa ilmu-ilmu sekuler yang dikembangkan di sekolah dan di Perguruan Tinggi Umum dan ilmu-ilmu agama yang dikembangkan di madrasah, pesantren dan Perguruan Tinggi Agama secara terpisah seperti yang sekarang ini berjalan sedang terjangkit krisis relevansi (tidak dapat memecahkan banyak soal), mengalami kemandegan dan kebuntuan (tertutup untuk pencarian alternatif-alternatif yang lebih mensejahterakan) dan penuh bias-bias kepentingan disana sini (filosofis, ortodoksi keagamaan, etnis, ekonomis, politik, gender, peradaban). Dari latar belakang seperti itu, gerakan rapproachment (kesediaan untuk saling menerima keberadaan yang lain dengan lapang dada) antara dua kubu keilmuan adalah merupakan keniscayaan. Gerakan rapproachment, untuk dapat menyebutnya juga sebagai gerakan integrasi epistemologi keilmuan adalah sesuatu yang mutlak diperlukan untuk mengantisipasi perkembangan-perkembangan yang serba kompleks dan tak terduga pada milenium ketiga serta tanggungjawab kemanusiaan bersama secara global dalam mengelola sumberdaya alam yang serba terbatas dan sumber daya manusia yang berkualitas sebagai khalifah fi al-ardli. ${ }^{6}$

Perlu diketahui bahwa ilmu sebagai ilmu tidak akan pernah menjadi muslim atau kafir. Ini berlaku bagi bidang keilmuan apa saja, baik ilmu yang selama ini disohorkan sebagai ilmu agama. Sains, baik yang alamiah maupun yang sosial adalah netral, artinya tidak mengandung nilai kebaikan atau kejahatan pada dirinya. Nilainya diberikan oleh manusia yang menguasainya. Sebagaimana halnya dengan apa saja yang netral, sains dapat dipergunakan untuk tujuan-tujuan yang bermanfaat atau yang merusak. ${ }^{7}$

${ }^{6}$ Amin Abdullah, Islamic....., 97

${ }^{7}$ Nurcholis Majid, Masa Depan Islam Dalam Majalah INOVASI, (Yogyakarta: UMY, 1991), 268. 
Lebih luas lagi, Perguruan Tinggi Agama khususnya IAIN, STAIN dan UIN secara sadar harus berani mengkaji ulang visi, misi dan paradigma keilmuan yang dibangun dan dipeliharanya. Begitu juga Perguruan-Perguruan Tinggi Umum yang sudah mapan dan berjalan selama ini. Ide dan usulan perlunya dikembangkan ilmuilmu sosial politik dan Kajian Agama secara kontekstual di Perguruan Tinggi Umum adalah merupakan tanda adanya keprihatinan yang serius tentang arah pengembangan dan tujuan pembelajaran ilmu-ilmu agama pada perguruan tinggi umum yang telah berjalan selama ini. Bangunan ilmu pengetahuan yang dikotomik antara ilmu pengetahuan umum dan ilmu pengetahuan agama harus diubah menjadi bangunan keilmuan baru yang lebih integralistik atau paling tidak keduanya bersifat komplementer. Filsafat Pendidikan Islam yang baru, yang perlu dijadikan acuan dan sekaligus tujuan pendidikan UIN, IAIN dan STAIN sebagai produsen ilmu pengetahuan yang akan menjadi feeder bagi tenaga guru madrasah dan sekolah, pengelola dan pengurus yayasan yang dimiliki sekolah atau madrasah haruslah diorientasikan pada lahirnya sarjana yang memiliki lima kemampuan, yaitu kemampuan menganalisis persoalan sosial-keagamaan secara akademik dan komprehensif (intelectual capital building), kemampuan melakukan inovasi yang terencana dan berkesinambungan (entre preneurial capital building), kemampuan memimpin sesuai dengan tuntutan persoalan kemasyarakatan, keilmuan, maupun profesi yang kemampuan membangun jaringan dan hubungan sosial kemasyarakatan yang luas (social capital building) ditekuninya (institutional capital building), dalam satu tarikan nafas etos keilmuan dan keagamaan yang terpadu (spiritual capital building). ${ }^{8}$

\section{Program Integrasi Keilmuan Teoantroposentris-Integralistik.}

Agama merupakan wahyu Tuhan, yang mengatur hubungan manusia dengan Tuhan, diri sendiri, dan lingkungan hidup baik fisik, sosial maupun budaya. Kitab suci Al-Qur'an yang diturunkan merupakan petunjuk etika, moral, akhlak, kebijaksanaan dan dapat menjadi teologi ilmu serta Grand Theory ilmu. Wahyu tidak pernah mengklaim sebagai ilmu qua ilmu seperti yang seringkali diklaim oleh ilmu-ilmu sekuler. ${ }^{9}$

\footnotetext{
${ }^{8}$ Amin Abdullah, Islamic....., 98.

${ }^{9}$ Fuad Jabali, Modernisasi Islam di Indonesia, (Jakarta: Logos Wacana Ilmu, 2002), 123-125.
} 
Agama memang mengklaim sebagai sumber kebenaran, etika, hukum, kebijaksanaan, dan sedikit pengetahuan. Agama tidak pernah menjadikan wahyu Tuhan sebagai satu-satunya sumber pengetahuan dan melupakan Tuhan. Menurut pandangan ini, sumber pengetahuan itu dua macam, yaitu yang berasal dari Tuhan dan yang berasal dari manusia. Perpaduan antara keduanya disebut teoantroposentrisme.

Modernisme yang menghendaki diferensiasi yang ketat dalam berbagai bidang kehidupan sudah tidak sesuai lagi dengan semangat zaman. Spesialisasi dan penjurusan yang sempit dan dangkal mempersempit jarak pandang atau horizon berpikir. Pada peradaban yang disebut pasca modern perlu ada perubahan. Perubahan dimaksud adalah gerakan resakralisasi, deprivatisasi agama dan ujungnya adalah dediferensiasi (rujuk kembali). Kalau diferensiasi menghendaki pemisahan antara agama dan sektorsektor kehidupan lain, maka dediferensiasi inilah penyatuan kembali agama dengan sektor-sektor kehidupan lain, termasuk agama dan ilmu.

Agama menyediakan tolok ukur kebenaran ilmu (daruriyyat; benar, salah), bagaimana ilmu diproduksi (hajiyyat; baik, buruk), tujuan-tujuan ilmu (tahsiniyyat; manfaat, merugikan) dan dimensi aksiologi dalam teologi ilmu ini penting untuk digarisbawahi, sebelum manusia keluar mengembangkan ilmu. Selebihnya adalah hak manusia untuk memikirkan dinamika internal ilmu.

Ilmu yang lahir dari induk agama menjadi ilmu yang objektif (objektifikasi). Artinya, suatu ilmu tidak dirasakan oleh pemeluk agama lain, non-agama, dan anti-agama sebagai norma tetapi sebagai gejala keilmuan yang objektif semata. Meyakini latar belakang agama yang menjadi sumber ilmu atau tidak, tidak menjadi masalah. Ilmu yang berlatarbelakang agama adalah ilmu yang objektif, bukan agama yang normatif. Maka, objektifikasi ilmu adalah ilmu dari orang beriman untuk seluruh manusia, tidak hanya untuk orang beriman saja. Contoh objektifikasi: akupuntur (tanpa harus percaya konsep Yin-Yang Taoisme), pijet (tanpa harus percaya konsep animisme-dinamisme dalam budaya leluhur), yoga (tanpa harus percaya Hindhuisme), sengatan lebah (tanpa harus percaya kepada Al-Qur'an yang memuji lebah), perbankan Syari'ah (tanpa harus meyakini Etika Islam tentang ekonomi). ${ }^{10}$

${ }^{10}$ Ibid, 129 
Selama ini para cerdik pandai telah tertipu. Ilmu-ilmu sekuler yang mengklaim sebagai value free ternyata penuh muatan kepentingan. Kepentingan itu diantaranya ialah dominasi kebudayaan (seperti Orientalisme), kepentingan ekonomi (seperti sejarah ekspansi negara-negara kuat era globalisasi), dan kepentingan militer/perang (seperti ilmu-ilmu nuklir). Ilmu yang lahir bersama etika agama tidak boleh memihak atau partisan seperti itu. Produk keilmuan harus bermanfaat untuk manusia seluruh umat manusia (rahmatan lil 'alamin).

Paradigma keilmuan baru yang menyatukan, bukan sekedar menggabungkan, wahyu Tuhan dan temuan pikiran manusia (ilmuilmu integralistik) tidak akan berakibat mengecilkan peran Tuhan (sekularisme) atau mengucilkan manusia sehingga teralienasi dari dirinya sendiri, dari masyarakat sekitar, dan lingkungan hidup sekitarnya. Diharapkan konsep integralisme dan reintegrasi epistemologi keilmuan akan sekaligus menyelesaikan konflik antar ekstrim dan agama-agama yang rigid dan radikal dalam banyak hal.

Dengan demikian, ilmu-ilmu yang diajarkan khususnya IAIN harus menyesuaikan konteks global. Untuk hal ini, para sarjana Islam di beberapa negara telah melakukan perombakan terhadap pembidangan ilmu yang ingin diajarkan kepada mahasiswanya. ${ }^{11}$

\section{Hakikat Integrasi Keilmuan Ke-Islam-an}

Menyusun dan merumuskan konsep integrasi keilmuan tentulah tidak mudah. Apalagi berbagai upaya yang selama ini dilakukan oleh beberapa perguruan tinggi Islam, terutama di Indonesia, dengan cara memasukkan beberapa program studi ke-Islam-an diklaim sebagai bagian dari proses integrasi keilmuan. Dalam praktek kependidikan di beberapa negara, termasuk di Indonesia, integrasi keilmuan juga memiliki corak dan jenis yang beragam. Lagi pula merumuskan integrasi keilmuan secara konsepsional dan filosofis, perlu melakukan kajian filsafat dan sejarah perkembangan ilmu, khususnya di kalangan pemikir dan tradisi keilmuan Islam. ${ }^{12}$

Untuk memberikan pemahaman yang memadai tentang konsep integrasi keilmuan, yang pertama-tama perlu dilakukan adalah memahami konteks munculnya ide integrasi keilmuan tersebut. Bahwa selama ini di kalangan umat Islam terjadi suatu pandangan

\footnotetext{
11 Akh. Minhaji, Masa Depan Pembidangan Ilmu di Perguruan Tinggi Agama Islam, (Yogyakarta:Ar-Ruzz Media, 2003), 50

12 Nasim Butt, Sains dan Masyarakat Islam, (Bandung: Pustaka Hidayah, 1996), 75
} 
dan sikap yang membedakan antara ilmu-ilmu ke-Islam-an di satu sisi, dengan ilmu-ilmu umum di sisi lain. Ada perlakukan diskriminatif terhadap dua jenis ilmu tersebut. Umat Islam seolah terbelah antara mereka yang berpandangan positif terhadap ilmuilmu ke-Islam-an sambil memandang negatif yang lainnya, dan mereka yang berpandangan positif terhadap disiplin ilmu-ilmu umum sembari memandang negatif terhadap ilmu-ilmu ke-Islaman. Kenyataan itu telah melahirkan pandangan dan perlakuan yang berbeda terhadap ilmuwan. Inilah yang dimaksud M. Amir Ali sebagai, ${ }^{13}$

"The definition of a scholar should be developed and applied to all equally In our times agraduate of an Islamic madrassah may be equivalent to bachelor degree holder but he is instantly called an 'alim (scholar). On the other hand a bachelor degree holder in chemistry or economics is not considered an 'alim (scholar)".

Definisi seorang ulama harus diterapkan dalam semua bidang keilmuan, karena pada saat lulus dari sebuah sekolah Islam yang setara dengan gelar sarjana, mereka langsung disebut ulama. Sedangkan pemegang gelar sarjana dalam bidang kimia maupun ekonomi tidak dianggap sebagai ulama'.

Dari konteks yang melatari munculnya ide integrasi keilmuan tersebut, maka integrasi keilmuan pertama-tama dapat dipahami sebagai upaya membangun suatu pandangan dan sikap yang positif terhadap kedua jenis ilmu yang sekarang berkembang di dunia Islam. M. Amir Ali kemudian memberikan pengertian integrasi keilmuan. ${ }^{14}$

"Integration of sciences means the recognition that all true knowledge is from Allah and all sciences should be treated with equal respect whether it is scientific or revealed".

Integrasi ilmu berarti pengakuan bahwa semua pengetahuan sejati adalah dari Allah dan semua ilmu harus diperlakukan dengan hormat yang sama apakah itu ilmiah atau terungkap.

Beberapa ayat Al-Qur'an yang digunakan oleh para pemikir Muslim untuk mendukung konsep integrasi keilmuan ini (all true knowledge is from Allah) di antaranya adalah:

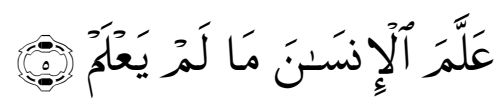

\footnotetext{
13 Usman Hassan, The Concept of Ilm and Knowledge in Islam, (The Association of Muslim Scientists and Engineers, 2003), 3

14 Ibid, 5
} 
"Dia mengajarkan kepada manusia apa yang tidak diketahuinya". (Q.S. Al-'Alaq: 5)

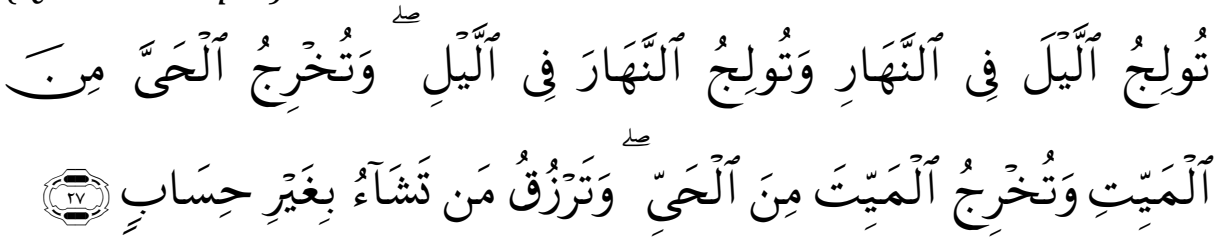

"Engkau masukkan malam ke dalam siang dan Engkau masukkan siang ke dalam malam. Engkau keluarkan yang hidup dari yang mati, dan Engkau keluarkan yang mati dari yang hidup. Dan Engkau beri rezki siapa yang Engkau kehendaki tanpa hisab (batas)." (Q.S. Ali-Imran: 27)

Konsep integrasi keilmuan juga berangkat dari doktrin keesaan Allah (tauhid), sebagaimana Tuhan, atau iman dalam pandangan Isma'il Razi al-Faruqi, bukanlah semata-mata suatu kategori etika. Ia adalah suatu kategori kognitif yang berhubungan dengan pengetahuan dengan kebenaran proposisi-proposisinya. Dan karena sifat dari kandungan proposisinya sama dengan sifat dari prinsip pertama logika dan pengetahuan, metafisika, etika, dan estetika, maka dengan sendirinya dalam diri subjek ia bertindak sebagai cahaya yang menyinari segala sesuatu. ${ }^{15}$

Sebagaimana prinsip-prinsip petunjuk Islam dan dengan menentukan prioritas penelitiannya serta implementasi proyek atas dasar nilai-nilai tersebut. Fungsi nilai-nilai negatif seperti haram, zhulm, dan dhiya ditegakkan untuk mempertahankan seluruh aktivitas sains dalam kerangka tolok ukur yang bisa diterima etika. Manakala batas-batas yang dibenarkan oleh sains Islam dilanggar, maka nilai-nilai negatif ini ditegakkan untuk mempertahankan etika masyarakat Islam.

Inti konsep paradigma sains Islam adalah Tauhid, khilafah, dan ibadah. Ketiga prinsip tersebut menjabarkan peran dan tujuan kehidupan manusia, membuat kehidupan manusia dan alam semesta menjadi lebih berarti. Ilmuwan Muslim dan lembagalembaga serta pusat sains Islam seharusnya memiliki tujuan utama meningkatkan keadilan dan kemaslahatan manusia, sementara dalam waktu yang bersamaan mampu meredam atau menekan z\}ulm dan d\}iya. Setiap program penelitian yang memungkinkan untuk diterapkan harus sepenuhnya ditinjau-ulang guna meyakinkan bahwa ia bukanlah ketidakadilan secara ekonomi,

15 Isma'il Razi al-Faruqi, Al-Tauhid: Its Implications for Thought and Life, (Virginia-USA: The International Institute of Islamic Thought, 1992), 42 
sosial, atau budaya. Setiap usaha penelitian dan proyek yang destruktif (dalam arti secara fisik, sosial, ekonomi, budaya, spiritual dan lingkungan) harus dicegah, karena sains dan teknologi semacam ini dapat memancing pola konsumtif yang merajalela. Sekarang ini kita menyaksikan semacam teknologi yang liar dalam keterasingan dan dehumanisasi sebagian besar lapisan kemanusiaan. Ini merupakan karakteristik utama sains yang zalim atau tiranik yang mengakibatkan kerusakan sumber daya alam, manusia dan spiritual. ${ }^{16}$

\section{Model-Model Integrasi Keilmuan}

Merumuskan model-model integrasi keilmuan secara konsepsional memang tidak mudah. Hal ini terjadi karena berbagai ide dan gagasan integrasi keilmuan muncul secara sporadis baik konteks tempatnya, waktunya, maupun argumen yang melatarbelakanginya. Faktor yang terkait dengan gagasan ini juga tidak tunggal. Ada beberapa faktor yang terkait dengannya, yakni sejarah tentang hubungan sains dengan agama kuatnya tekanan dari kelompok ilmuwan yang menolak doktrin "bebas nilai"-nya sains, krisis yang diakibatkan oleh sains dan teknologi dan ketertinggalan umat Islam dalam bidang ilmu dan teknologi. Dari faktor-faktor yang mendorong munculnya gagasan integrasi keilmuan tersebut, secara umum modal integrasi keilmuan dapat dikelompokkan ke dalam model-model berikut ini:

1. Model IFIAS

Model integrasi keilmuan IFIAS (International Federation of Institutes of Advance Study) muncul pertama kali dalam sebuah seminar tentang "Knowledge and Values", yang diselenggarakan di Stickholm pada September 1984. Model yang dihasilkan dalam seminar itu dirumuskan dalam gambar skema berikut ini:

16 Ibid, 45 


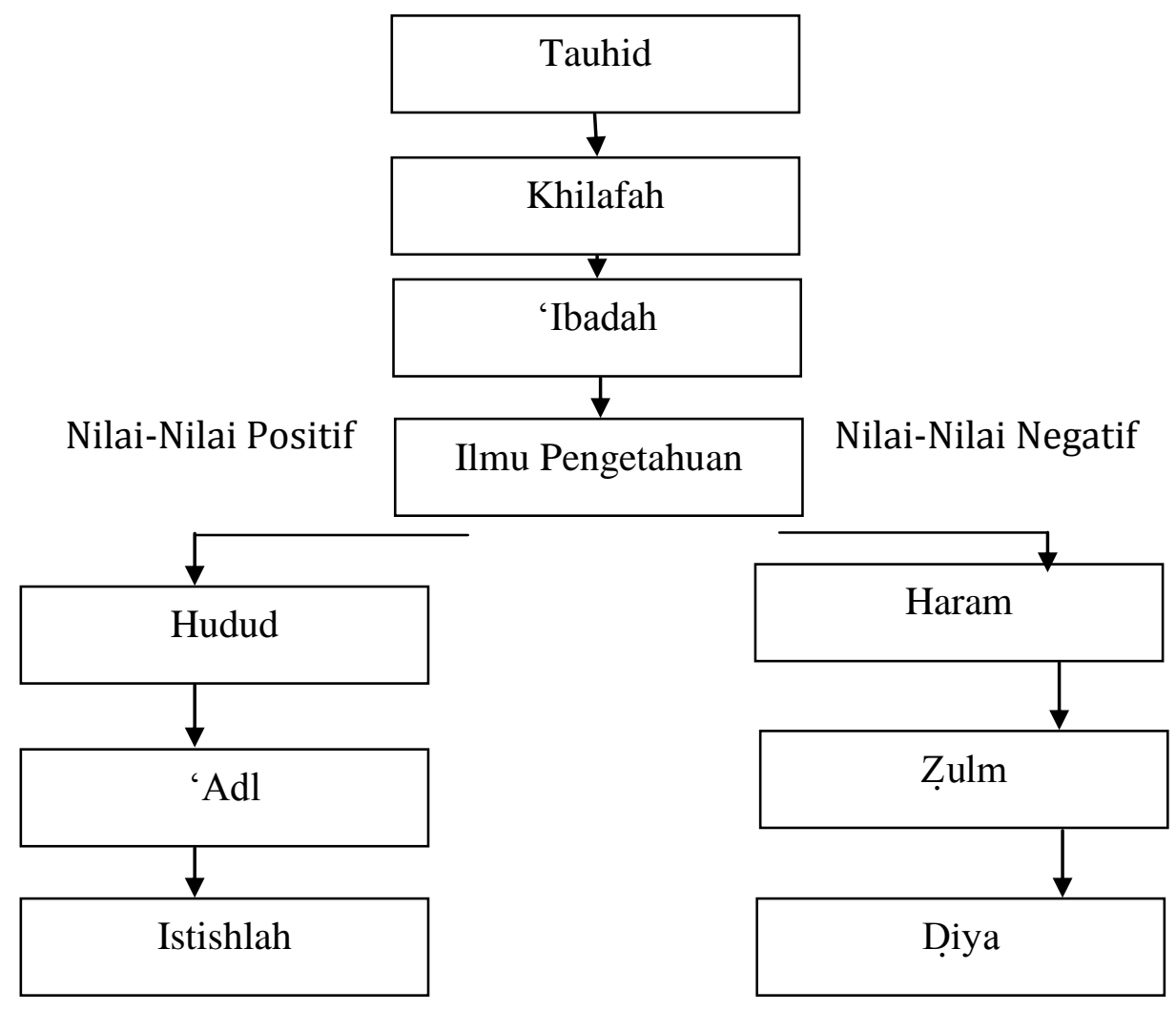

Skema di atas kurang lebih dapat dijelaskan sebagai berikut: Iman kepada Sang Pencipta membuat ilmuwan Muslim lebih sadar akan segala aktivitasnya. Mereka bertanggungjawab atas perilakunya dengan menempatkan akal di bawah otoritas Tuhan. Karena itu, dalam Islam, tidak ada pemisahan antara sarana dan tujuan sains. Keduanya tunduk pada tolok ukur etika dan nilai keimanan. Ia harus mengikuti prinsip bahwa sebagai ilmuwan yang harus mempertanggungjawabkan seluruh aktivitasnya pada Tuhan, maka ia harus menunaikan fungsi sosial sains untuk melayani masyarakat, dan dalam waktu yang bersamaan melindungi dan meningkatkan institusi etika dan moralnya. Dengan demikian, pendekatan Islam pada sains dibangun di atas landasan moral dan etika yang absolut dengan sebuah bangunan yang dinamis berdiri di atasnya. Akal dan objektivitas dianjurkan dalam rangka menggali ilmu pengetahuan ilmiah, di samping menempatkan upaya intelektual dalam batas-batas etika dan nilai-nilai Islam.

Anjuran nilai-nilai Islam abadi seperti khilafa, ibadah, dan adl adalah aspek subjektif sains Islam. Emosi, penyimpangan, dan prasangka manusia harus disingkirkan menuju jalan tujuan 
mulia tersebut melalui penelitian ilmiah. Objektivitas lembaga sains itu berperan melalui metode dan prosedur penelitian yang dimanfaatkan guna mendorong formulasi bebas, pengujian dan analisis hipotesis, modifikasi, dan pengujian kembali teori-teori itu jika mungkin. Karena sains menggambarkan dan rnenjabarkan aspek realitas yang sangat terbatas, ia dipergunakan untuk mengingatkan kita akan keterbatasan dan kelemahan kapasitas manusia. Al-Qur'an juga mengingatkan kita agar sadar pada keterbatasan kita sebelum terpesona oleh keberhasilan penemuan-penemuan sains dan hasil-hasil penelitian ilmiah.

2. Model Akademi Sains Islam Malaysia (ASASI)

Model yang dikembangkan oleh Akademi Sains Islam Malaysia (ASASI) muncul pertama kali pada Mei 1977 dan merupakan satu usaha yang penting dalam kegiatan integrasi keilmuan Islam di Malaysia karena untuk pertamanya, para ilmuwan Muslim di Malaysia bergabung untuk, antara lain, menghidupkan tradisi keilmuan yang berdasarkan pada ajaran Kitab suci al-Qur'an. Tradisi keilmuan yang dikembangkan melalui model ASASI ini pandangan bahwa ilmu tidak terpisah dari prinsip-prinsip Islam. Model ASASI ingin mendukung dan mendorong pelibatan nilai-nilai dan ajaran Islam dalam kegiatan penelitian ilmiah; menggalakkan kajian keilmuan di kalangan masyarakat; dan menjadikan Al-Qur'an sebagai sumber inspirasi dan petunjuk serta rujukan dalam kegiatan-kegiatan keilmuan. ASASI mendukung cita-cita untuk mengembalikan bahasa Arab, selaku bahasa Al-Qur'an, kepada kedudukannya yang hak dan asli sebagai bahasa ilmu bagi seluruh Dunia Islam, dan berusaha menyatukan ilmuwan-ilmuwan Muslim ke arah memajukan masyarakat Islam dalam bidang sains dan teknologi.

3. Model Islamic Worldview

Model ini berangkat dari pandangan bahwa pandangan dunia Islam (Islamic worldview) merupakan dasar bagi epistemologi keilmuan Islam secara menyeluruh dan integral. Dua pemikir Muslim ini menggagas dan mengembangkan model ini adalah Alparslan Acikgenc, Guru Besar Filsafat pada Fatih University, Istanbul Turki. Ia mengembangkan empat pandangan dunia Islam sebagai kerangka komprehensif keilmuan Islam, yaitu: iman sebagai dasar struktur dunia (world structure,iman), ilmu sebagai struktur pengetahuan (knowledge structure, al-'ilm), fiqih sebagai struktur nilai (value structure, al-fiqh); dan 
kekhalifahan sebagai struktur manusia (human structure, khalîfah).

4. Struktur Pengetahuan Islam

Model Struktur Pengetahuan Islam (SPI) banyak dibahas dalam berbagai tulisan Osman Bakar, Professor of Philosophy of Science pada University of Malaya. Dalam mengembangkan model ini, Osman Bakar berangkat dari kenyataan bahwa ilmu secara sistematik telah diorganisasikan dalam berbagai disiplin akademik. Bagi Osman Bakar, membangun SPI sebagai bagian dari upaya mengembangkan hubungan yang komprehensif antara ilmu dan agama, hanya mungkin dilakukan jika umat Islam mengakui kenyataan bahwa pengetahuan (knowledge) secara sistematik telah diorganisasikan dan dibagi ke dalam sejumlah disiplin akademik.

Osman Bakar mengembangkan empat komponen yang ia sebut sebagai struktur pengetahuan teoretis (the theoretical structure of science). Keempat struktur pengetahuan itu adalah: komponen pertama berkenaan dengan apa yang disebut dengan subjek dan objek matter ilmu yang membangun tubuh pengetahuan dalam bentuk konsep (concepts), fakta (facts, data), teori (theories), dan hukum atau kaidah ilmu (laws), serta hubungan logis yang ada padanya, komponen kedua terdiri dari premis-premis dan asumsi-asumsi dasar yang menjadi dasar epistemologi keilmuan, komponen ketiga berkenaan dengan metode-metode pengembangan ilmu dan komponen terakhir berkenaan dengan tujuan yang ingin dicapai oleh ilmu.

5. Model Bucaillisme

Model ini menggunakan nama salah seorang ahli medis Perancis, Maurice Bucaille, yang pernah menggegerkan dunia Islam ketika menulis suatu buku yang berjudul "La Bible, le Coran et la Science", yang juga telah diterjemahkan ke dalam bahasa Indonesia. Model ini bertujuan mencari kesesuaian penemuan ilmiah dengan ayat Al-Qur'an. Model ini banyak mendapat kritik, lantaran penemuan ilmiah tidak dapat dijamin tidak akan mengalami perubahan di masa depan. Menganggap Al-Qur'an sesuai dengan sesuatu yang masih bisa berubah berarti menganggap Al-Qur'an juga bisa berubah. ${ }^{17}$

6. Model Integrasi Keilmuan Berbasis Filsafat Klasik

Model Integrasi Keilmuan Berbasis Filsafat Klasik berusaha menggali warisan filsafat Islam klasik. Salah seorang sarjana

17 A. Rasyidi, Terjemahan Bibel Qur'an dan Sains,(Jakarta: Bulan Bintang, 1992), 41 
yang berpengaruh dalam gagasan model ini adalah Seyyed Hossein Nasr. Menurut Seyyed Hossein Nasr pemikir Muslim klasik berusaha memasukkan Tauhid ke dalam skema teori mereka. Prinsip Tauhid, yaitu Kesatuan Tuhan dijadikan sebagai prinsip kesatuan alam tabi'i. Para pendukung model ini juga yakin bahwa alam tabi'i hanyalah merupakan tanda atau ayat bagi adanya wujud dan kebenaran yang mutlak. Hanya Allah-lah Kebenaran sebenar-benarnya, dan alam tabi'i ini hanyalah merupakan wilayah kebenaran terbawah. ${ }^{18}$

7. Model Integrasi Keilmuan Berbasis Tasawuf

Pemikir yang terkenal sebagai penggagas integrasi keilmuan Islam yang dianggap bertitik tolak dari tasawwuf ialah Syed Muhammad Naquib al-Attas, yang kemudian ia istilahkan dengan konsep Islamisasi Ilmu Pengetahuan (Islamization of Knowledge). Gagasan ini pertama kali muncul pada saat konferendi Makkah, di mana pada saat itu, Al-Attas menghimbau dan menjelaskan gagasan "Islamisasi Ilmu Pengetahuan". Identifikasinya yang meyakinkan dan sistematis mengenai krisis epistemologi umat Islam sekaligus formulasi jawabannya dalam bentuk Islamisasi ilmu pengetahuan masa kini yang secara filosofis berkaitan, benar-benar merupakan prestasi inovatif dalam pemikiran Islam modern. Formulasi awal dan sistematis ini merupakan bagian integral dan konsepsinya mengenai pendidikan dan universitas Islam serta kandungan dan metode umumnya. Karena kebaruan ide-ide yang dipresentasikan dalam kertas kerjanya di Makkah, tema-tema gagasan ini diulas kembali dan dijelaskan panjang lebar pada Konferensi Dunia yang Kedua mengenai Pendidikan Umat Islam pada 1980 di Islamabad. Dalam karya-karyanya, dia mencoba menghubungkan deislamisasi dengan westernisasi, meskipun tidak secara keseluruhan. Dari situ, dia kemudian menghubungkan program Islamisasi ilmu pengetahuan masa kini dengan dewesternisasi. Predikat ilmu masa kini" sengaja digunakan sebab ilmu pengetahuan yang diperoleh umat Islam yang berasal dari kebudayaan dan peradaban pada masa lalu, seperti Yunani dan India, telah diislamkan. Gagasan awal dan saran-saran yang konkret ini, tak pelak lagi, mengundang

18 Wan Daud, Wan Ramli bin dan Shaharir bin Mohamad Zain, "Pemelayuan, Pemalaysiaan dan Pengislaman Ilmu Sains dan Teknologi dalam Konteks Dasar Sains Negara", Jurnal Kesturi, Nomor 1 (1999), 14-15. 
pelbagai reaksi dan salah satunya dari almarhum Isma'il AlFaruqi dengan agenda Islamisasi Ilmu Pengetahuannya. ${ }^{19}$

8. Model Integrasi Keilmuan Berbasis Fiqh

Model ini digagas oleh Al-marhum Ismail Raji al-Faruqi. Pada tahun 1982 ia menulis sebuah buku berjudul Islamization of Knowledge: General Principles and Work Plan diterbitkan oleh International Institute of Islamic Thought, Washinton. Menjadikan Al-Faruqi sebagai penggagas model integrasi keilmuan berbasis fiqh memang tidak mudah, lebih-lebih karena ia termasuk pemikir Muslim pertama yang mencetuskan gagasan perlunya Islamisasi Ilmu Pengetahuan. Masalahnya pemikiran integrasi keilmuan Islam Al-Faruqi tidak berakar pada tradisi sains Islam yang pernah dikembangkan oleh AlBiruni, Ibnu Sina, Al-Farabi dan lain, melainkan berangkat dari pemikiran ulama fiqh dalam menjadikan Al-Qur'an dan Assunnah sebagai puncak kebenaran. Kaidah fiqh ialah kaedah penentuan hukum fiqh dalam ibadah yang dirumuskan oleh para ahli fiqh Islam melalui deduksi Al-Qur'an dan keseluruhan korpus al-Hadith. Pendekatan ini sama sekali tidak menggunakan warisan sains Islam yang dipelopori oleh Ibn Sina, al-Biruni dan sebagainya. Bagi al-Faruqi, "sains Islam" seperti itu tidak Islami karena tidak bersumber dari teks Al-Qur'an dan Hadis.

9. Model Kelompok Ijmali (Ijmali Group)

Pendekatan Ijmali dipelopori oleh Ziauddin Sardar yang memimpin sebuah kelompok yang di namainya Kumpulan Ijmali (Ijmali Group). Menurut Ziauddin Sardar tujuan sains Islam bukan untuk mencari kebenaran akan tetapi melakukan penyelidikan sains menurut kehendak masyarakat Muslim berdasarkan etos Islam yang digali dari Al-Qur'an. Sardar yakin bahwa sains adalah sarat nilai (value bounded) dan kegiatan sains lazim dijalankan dalam suasana pemikiran atau paradigma tertentu. Pandangan ini mengikuti konsep paradigma ilmu Thomas Kuhn. Sardar juga menggunakan konsep 'adl dan zulm sebagai kriterium untuk dilaksanakan. Walaupun Sardar yakin dengan pendekatan Kuhn yang bukan hanya merujuk kepada sistem nilai saja, tetapi kebenaran sains itu sendiri, namun ia tidak langsung membicarakan kebenaran teori sains Barat itu sendiri. Pandangan Sardar ini seakan-akan menerima semua penemuan sains Barat modern dan hanya prihatin terhadap

19 Syed M. Naquib al-Attas, Islam dan Sekularisme, (Kuala Lumpur : Angkatan Muda Belia Islam Malaysia, ABIM, 1978), 43-44 
sistem nilai atau etos yang mendasari sains tersebut. Dengan menggunakan beberapa istilah dari Al-Qur'an seperti Tawhîd, 'ibadah, khilafah, halal, haram, taqwa, 'ilm dan istislah. Hampir senada dengan al-Faruqi, konsep-konsep yang dikemukakan oleh Sardar tidak merujuk pada tradisi sains Islam klasik. Bagi Sardar sains adalah "is a basic problem-solving tool of any civilization" (perangkat pemecahan masalah utama setiap peradaban)..$^{20}$

10. Model Kelompok Aligargh (Aligargh Group)

Model ini dipelopori oleh Zaki Kirmani yang memimpin Kelompok Aligargh University, India. Model Kelompok Aligargh menyatakan bahwa sains Islam berkembang dalam suasana 'ilm dan tasykir untuk menghasilkan gabungan ilmu dan etika. Pendek kata, sains Islam adalah sekaligus sains dan etika. Zaki Kirmani menetapkan model penelitian yang berdasarkan berdasarkan wahyu dan taqwa. Ia juga mengembangkan struktur sains Islam dengan menggunakan konsep paradigma Thomas Kuhn. Kirmani kemudian menggagas makroparadigma mutlak, mikroparadigma mutlak, dan paradigma bayangan. ${ }^{21}$

\section{Kesimpulan}

Dari beberapa pembahasan diatas, maka penulis dapat mengambil kesimpulan bahwa: Hingga kini, masih kuat anggapan dalam masyarakat luas yang mengatakan bahwa "agama" dan "ilmu", "madrasah" dan "sekolah" adalah dua entitas yang tidak bisa dipertemukan. Keduanya mempunyai wilayah sendiri-sendiri, terpisah antara satu dan lainnya, baik dari segi objek formalmaterial keilmuan, metode penelitian, kriteria kebenaran, peran yang dimainkan oleh ilmuwan maupun status teori masing-masing bahkan sampai ke institusi penyelenggaraannya

Paradigma keilmuan baru yang menyatukan, bukan sekedar menggabungkan, wahyu Tuhan dan temuan pikiran manusia (ilmuilmu integralistik) tidak akan berakibat mengecilkan peran Tuhan (sekularisme) atau mengucilkan manusia sehingga teralienasi dari dirinya sendiri, dari masyarakat sekitar, dan lingkungan hidup sekitarnya.

Menyusun dan merumuskan konsep integrasi keilmuan tentulah tidak mudah. Apalagi berbagai upaya yang selama ini dilakukan

\footnotetext{
20 Ibid.

21 Wan Daud, Wan Ramli bin dan Shaharir bin Mohamad Zain, Pemelayuan, Pemalaysiaan dan Pengislaman.. 14-15
} 
oleh beberapa perguruan tinggi Islam, terutama di Indonesia, dengan cara memasukkan beberapa program studi ke-Islam-an diklaim sebagai bagian dari proses integrasi keilmuan.

Merumuskan model-model integrasi keilmuan secara konsepsional memang tidak mudah. Hal ini terjadi karena berbagai ide dan gagasan integrasi keilmuan muncul secara sporadis baik konteks tempatnya, waktunya, maupun argumen yang melatarbelakanginya.

\section{Daftar Pustaka}

Abdullah, Amin. Islamic Studies, (Bandumg: Pustaka Pelajar, 2006) Al-Faruqi, Isma'il Razi. Al-Tauhid: Its Implications for Thought and Life, (Virginia-USA: The International Institute of Islamic Thought, 1992)

Anees, Munawar Ahmad. Menghidupkan Kembali Ilmu Dalam Jurnal-Jurnal Studi Islam, (Bandung: Yayasan Mutahhari, 1991)

Butt, Nasim. Sains dan Masyarakat Islam, (Bandung: Pustaka Hidayah, 1996)

Daud, Wan Shaharir bin Mohamad Zain, Pemelayuan, Pemalaysiaan dan Pengislaman Ilmu Sains dan Teknologi dalam Konteks Dasar Sains Negara, Jurnal Kesturi, No. 1, 1991

Hassan, Usman. The Concept of Ilm and Knowledge in Islam, (The Association of Muslim Scientists and Engineers, 2003)

Jabali, Fuad. Modernisasi Islam di Indonesia, (Jakarta: Logos Wacana Ilmu, 2002)

Majid, Nurcholis, Masa Depan Islam Dalam Majalah INOVASI, (Yogyakarta: UMY, 1991)

Minhaji, Akh. Masa Depan Pembidangan Ilmu di Perguruan Tinggi Agama Islam, (Yogyakarta: Ar-Ruzz Media, 2003)

Rasyidi. Terjemahan Bibel Qur'an dan Sains, (Jakarta: Bulan Bintang, 1992)

Syed M. Naquib al-Attas. Islam dan Sekularisme, (Kuala Lumpur: Angkatan Muda Belia Islam Malaysia, ABIM, 1978)

Wardi, Moh. "Modernisasi Muallimin", Jurnal Ta'limuna al-Hikam Malang, Vol.7 No.1 Maret 2014.

Zainuddin. Filsafat Ilmu Perspektif Pemikiran Islam, (Malang: Lintas Pustaka, 2006) 